\title{
INVESTIGATING A PROFESSIONAL TEACHING OF THE NEW LECTURER IN INDONESIA
}

\author{
Muhammad Yunus \\ University of Islam Malang \\ m.yunus@unisma.ac.id \\ Ani Sukma Sari \\ University of Islam Malang \\ anisukmasari@gmail.com
}

\begin{abstract}
The concern held on this issue vary in term of English language teaching practices especially teaching speaking by the new speaking lecturer of University of Islam Malang (Unisma). The descriptive qualitative study was then designed in order to describe the teaching speaking activities by the new speaking lecturer of Unisma. Twice classroom observations were conducted in two different speaking classes. Moreover, the new lecturer and ten students from speaking II D \&II E were also invited to join twice interviews. By the same token, a simple questionnaire which consists of thirteen questions was also distributed to know students' involvement during speaking class. From the investigation, it was found out that the new lecturer has implemented procedural teaching performances such as preparing teaching activities - designing lesson planning, teaching journal and course outline, executing the plans in classroom creating group discussion, presentation and individual task, and assessing the progress after teaching and learning activities such as implementing oral test. Moreover, the observed students were motivated by the new lecturer teaching way. Additionally, the new lecturer only implemented ICT based learning as the supporting way to facilitate her teaching not as her main media.
\end{abstract}

Keywords: A New Lecturer, First Year Students, Teaching Speaking

\section{BACKGROUND}

Investigation of teaching a target language has continually shown a significant interest. One visible fact related to teaching a target language is revealed on Miller's study (2003) after being exemplified in Xuan (2014) that most of language learners have more challenges in learning speaking. From those researches, it can be assumed that some students still face some obstacles in learning speaking. Like in Indonesia, it is found that the challenges in teaching speaking are influenced by the social and learning environment during students' study. Also, some findings (Miller, 2003) related to the field founded by some researchers that are lacked right at the beginning of a talk was -linguistic and phonological knowledge.

Similarly, issues and trends of teaching of spoken English have academically gained a prominent concern so far particularly in English as a Foreign Language (EFL) classroom. This is because different areas of speaking, pronunciation and intonation, are considered as difficult to master completely. Therefore, this visible fact can be such a challenge for speaking lecturers in teaching speaking. Another challenge in teaching speaking comes from students' anxiety, and some of students are reluctant to speak. This is an impact of minimum vocabulary mastery, and they cannot express their ideas. 
For this reason, Xuan (2014) also mentioned that language educators and teachers can assist students to gain access to communicative events more both inside and outside the class. Within classroom, this can be done by encouraging students to move their positions around rather than sit in the same place every session. Moreover, organizing such warm - up activities as seeking information from classmates might encourage students to interact more and change their seating.

Yunus (2010), for example, implemented guided questions by having inside outside circle activities. This was done by Yunus to facilitate students providing such kind of scaffolding so that the students are willing to speak. In his research, Yunus' activities in his class is as follow; (1) brainstorming the students by asking them how to speak and great people for the first meeting, showing them pictures of students who introduce each other, (2) explaining guided questions through inside outside circle strategy, (3) giving clear instruction, (4) modeling the expected result of the task, (5) presentation, (6) making reflection toward the things that students just have in the process of the teaching and learning in the classroom. Therefore, guided questions through inside outside circle strategy give chance for students to share ideas in improving speaking fluently, vocabulary, and pronunciation (Yunus, 2010).

The studies above were chosen since the intense interest of the researchers focus on the description of a new lecturer in teaching speaking. A new speaking lecturer here can be defined as a lecturer who experiences in teaching speaking around one and half year. As revealed by Levy (1972) that new lecturer is commonly called as a young. Young in this case means he or she has new idea or something particularly fresh and exciting in their approach-what they generally have is a lot of learning to do. Equally important, after evaluating the concept of Babione and Shea (2005 as cited in Maskat, 2010), the reason for choosing a new lecturer as the subject of this study is to discover whether the new speaking lecturer has implemented the teaching and learning activities based on the standard curriculum. A new speaking lecturer who was chosen in this present study is a lecturer in English Department of University of Islam Malang who teaches the first-year students.

This study was carried out in order to describe teaching and learning speaking activities including instruments employed by the new lecturer such as Rencana Perkuliahan Semester (RPS)/lesson planning, teaching journal, assessment and teaching materials. Furthermore, classroom management - teaching techniques and teaching materials that are utilized by the new lecturer was elaborated as well in this present study. Specifically, the problems faced by the new lecturer in teaching speaking were also elaborated in this study, and how the new lecturer handles those problems as well. Last but not least, how the new lecturer assesses the students' performance in speaking class were also described as well.

\section{Materials in Teaching Speaking}

Mostly, the material in teaching speaking will be based on the topic provided by the lecturer. Generally, the lecturer decides the contextual topic as their teaching material in speaking. Richard (2014) wrote that information oriented and goods and services oriented are the example of material based on daily life topic. First, information oriented; the common topics utilized by the lecturer are that asking for directions, describing how to use something, and discussing plan. Second, goods and services oriented; this topic is usually in the form of checking into a hotel, shopping, ordering a hotel, and focus on achieving a goal or service.

\section{Speaking Classroom Management}

Creating a successful classroom management is one of inevitable things to be considered in teaching. How the lecturer manages the classroom can be influenced by 
several key factors. Shahsavar and Jamalzadeh (2016) pointed out that teacher performance during managing the classroom is affected by contextual factors such as classroom size and environment, instructional time, the amount of students' paperwork, using of technology in classrooms, instructional materials, and teaching environment.

\section{Speaking Assessment}

Assessing students' speaking performance will be carried out successfully if the lecturer knows what factors included in speaking assessment. As stated by $\mathrm{Li}(2014)$ that vocabulary is one of essential things to be considered in assessing speaking since vocabulary makes the language testers have been more interested in testing communicative or interactional competence. Besides that, to most people, especially for foreign learners, mastering the art of speaking is the single most important aspect of learning a second or foreign language, and success is measured in terms of the ability to carry out a conversation in the language. Learning English is different from learning Math. In Math learners just need to sit down and concentrate to the problems and they master Math, but in English they need to practice a lot (Yunus, 2010). Therefore, in assessing speaking, a new lecturer should comprehend what the components of speaking are, so that the test is valid.

\section{Output of Teaching Speaking}

Teaching practice will be more successful if it is supported by the output of teaching itself since the result of teaching will be the ultimate goal for the lecturer. Riahipour, Dabbaghi, and Ketabi (2014) wrote that the prior goal of Communicative Language Teaching (CLT) is communicative competence. It can be exemplified by the learners' ability to use the language correctly and appropriately to the situation, and ability to communicate completely, not necessarily the ability to use the language exactly as a native speaker. Additionally, they also described that the output of teaching speaking can be seen from learners' enthusiasm, academic performance, less frustration and difficulty in learning, more attitude and motivations toward learning.

\section{METHOD}

\section{Design}

The design of this study is descriptive qualitative. The choice of this design is to describe teaching speaking activities. Moreover, this research design has special characteristics. So, the study was conducted through twice classroom observations, and twice semi-structured interview sessions. Then, the data were recorded and interpreted in order to be analyzed. Additionally, to know students' engagement during speaking class, simple questionnaire then distributed to the students of speaking II D \&II E which consist of twenty-five students each class. Finally, the result of observations and interviews were combined.

\section{Participants}

The subject was selected from the new lecturer who teaches speaking around one and a half year. She was selected by using convenience sampling. To find supporting data, ten students from speaking II D\& II E were chosen as well.

\section{FINDINGS}

After having twice observations and twice interviews with the lecturer and the students as well, it was found out that the lecturer did several things in pre-teaching, during, and post teaching activities. Then, it was familiarized by translating the sections 
which contain respondents' explanation in Indonesian. Then, the researcher combined the result of observations and interviews.

\section{Lecturer's Plan and Preparation in Teaching Speaking}

The new lecturer prepared several teaching components such as Rencana Perkuliahan Semester (RPS), teaching journal, teaching assessment, and teaching material. RPS will be the lecturer's guidance in teaching speaking since it covers some important teaching components such as indicators, purpose of the study, teaching methods, and assessment criteria. On the one hand, the lecturer also has teaching journal which covers all topics for one semester specifically. Meanwhile, she had such a course design or teaching journal which provides all materials for one semester. She had to develop this teaching journal into specified material that will be learnt, for example: how to implement public speaking.

The observed lecturer implemented the manipulative material such as public speaking which was creatively designed and innovated by her. Interestingly, from the ideas, it can be said that the lecturer can provide such appropriate materials selections based on standard RPS of faculty of teacher training and education. For another learning media, the observed lecturer stated that she did not use regular book for speaking. She told that speaking skill is such a productive skill which requires real models and direct demonstration. Then, the observed lecturer sets score seventy as the standard score or KKM in her class depending on her students' ability. If they get below seventy they have to join remedial test.

\section{Lecturer's Strategies during Teaching Speaking}

The lecturer also often asked students to provide responses after their friend finished presenting the discussed topic, and actively guided the students by monitoring all students across the activities. Next, the lecturer always provided techniques to make all students participate actively during speaking class such as in a group discussion. The lecturer only randomly called one student as the representative to present their discussed topic. So, all students have to be ready.

\section{Lecturer's Learning Techniques during Teaching Speaking}

The lecturer's teaching way is based on what students' need in learning speaking. She used Discovery Based Learning as her main method. It was revealed in observation results when she asked her students to found at least five definitions about public speaking. Moreover, the lecturer also employed presentation in front of the class. Also, the lecturers always provided clear directions of assignment, and gave the corrective feedbacks for all students. Moreover, the lecturer actively involved all students to participate in individual, pair and group works as well. For group works, she intended to apply drama, discussion and learning media exhibition activities. Also, the lecturer usually gave equal turns in calling the students by preplanned system. For randomized selection, the lecturer did not only target for passive students a lot in order to involve supportive environment for students such as lottery for learning media exhibition and choosing randomly by herself like debate activities. This action was done in order to consider that the selected student is good in delivering the opinion so that he or she can help their friend.

\section{Students' Behaviors during Speaking Class}

This part presents relevant data as the result of questionnaire which shows that among fifty respondents involved in this study, many of them stated that they always paid attention and actively engaged in most of activities in speaking class. This data also indicated their involvement in group activities such as working together with the team to solve the given task and helping the group member during the presentation. Therefore, it 
can be said that the students can work cooperatively during speaking class in group discussion especially. Many of whom also voiced that they often express their opinions and ask questions during speaking class. One interesting finding is that they also usually get together with other students to discuss subjects or topics especially in group discussion. The respondents also mentioned that they sometimes offer suggestion to make the class better, and tell the lecturer what they are interested in.

\section{The Lecturer's Assessment in Speaking Class}

In the end of the teaching activities, the lecturer always monitored the students by reviewing and giving appropriate feedbacks to the students and continued the teaching progress. The new lecturer's teaching assessments rely on not only by having oral test, but also other activities which support the assessment of the students' development progress. Meanwhile, in some cases of her assessments, she purposely used specific aspects to be assessed, for example, focusing on contents and pronunciation, yet she did not fully pay attention to the students' fluency for certain topic likes speech.

\section{DISCUSSION}

The present research was purposed to describe the teaching and learning activities which were deployed by the new speaking lecturer of Unisma. This synthesis was aimed to analyze the phenomena inside of the teaching and learning speaking of the new speaking lecturer based on the views of the several studies.

Based on the recorded data in overall progress that started from pre-teaching, during teaching activities and post- teaching, it can be stated that the observed lecturer has already met the criteria of being a qualified lecturer. It is noted that presenting and applying standard procedures of teaching and learning activities may be distinct from one lecturer to another. After synthesizing Wiggins and McTighe's (2006: 6), the researcher clarified their ideas in Richard's (2013) study which found that the observed lecturer has maintained the content materials, input progress, and learning outcome into a teaching and learning system which met the students' progress during their study.

In fact, she employed the standard procedures in preparing, implementing and assessing the students based on the curriculum requirements. As Talley and Hui-ling (2014) observe that curriculum for teaching speaking skill should endeavor to expose learners to authentic, practical settings for speaking English and encourage active learner involvement in the lesson. The new lecturer's teaching procedure was stated in the Chart 1 below.

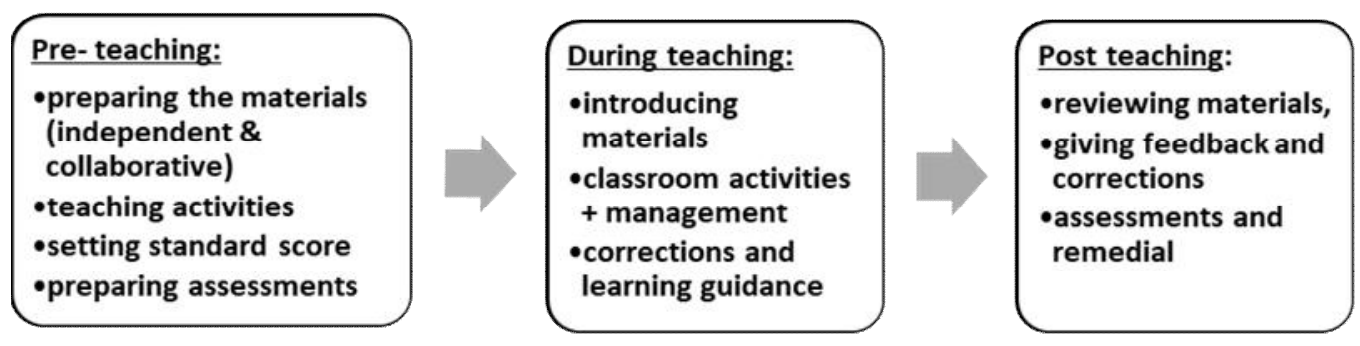

Chart 1: teaching and learning progress of the observed lecturer

The observed lecturer also exhibited potential performance as a professional educator behind her standard performances as a new lecturer as the chart of teaching progress had shown above. In another case, even though the observed lecturer still categorized as a new lecturer, she could provide and could maintain her materials that fit the students' needs, interest, and capabilities. 
Based on the result of findings, it is clear that the observed lecturer, somehow, implements individual and common group discussions that her former lecturers or teachers had implemented. As a result, the old culture still remained in the observed lecturer's classroom. Due to the limited experience, Maskat (2010) strongly recommended that the new lecturer should be able to observe his or her own teaching progress and to reflect every experience during the teaching time for a greater successful teaching career.

For learning media, she used physical materials such as books or the similar since she only used ICT based learning to support her teaching not as her main media in teaching speaking. In discovery learning, the new lecturers asked the students to give at least five definitions about public speaking and ask them write their own definitions. It means that the observed lecturer let her students manipulate activities by conducting experiments, then, by manipulating materials and indicators in the activity and observing the effects of these manipulations (Sab, et al., 2005). By conducting discovery learning (J. Swaak et al., 2004) it can be stated that the observed lecturer assumed that learners take an active participation and build their own basic knowledge.

In observed lesson during teaching speaking, the lecturer tried to integrate two classroom activities within a single lesson in order to achieve the integration of the four skills (listening, reading, speaking, and writing). It is proved by what lecturer did in a classroom that she employed a group discussion in which the students in each group must comprehend the given text (reading); therefore, they are asked to present their analysis toward the given text. The integrated techniques as like reading and speaking, writing and speaking, which the observed lecturer used, were aimed to combine teaching speaking in both content and language focus at the same time (Costales, 2014).

In delivering her teaching activities, the lecturer often implemented cooperative learning like group works to make the students actively engaged during speaking class. Many researchers have also proven that students are much readier to interact with each other with more complex responses than with their teacher (Achmad and Yusuf 2014: 151). Hence, students feel more comfortable working, interacting and making mistakes with their partners rather than with their teachers. Krashen (2005) recommends that learners should be motivated so that they do not feel threatened. The students also feel motivated since the lecturer always tries to provide them with many interesting and various topics during speaking class such as performing speech, learning media exhibition, and novel analysis. Those kinds of classroom activities can enhance student's active participation, motivate and expose students to authentic use of English language in context (Gudu, 2015).

To sum up, the new lecturer investigated in this study have shown that her activities are in line with the recent education reforms in Indonesia are a testimony of the country's commitment to competency-based education, where the emphasis is placed on higher-order thinking skills (Yunus, 2018). The HOT activities should be facilitated in the teaching of English skills, not only in reading but also in reading.

\section{CONCLUSION}

The findings on the current investigation showed that the new lecturer has employed the standard teaching procedures. Most of materials prepared by the new lecturer met the students' need such as public speaking. This topic can encourage student to be more active during speaking class. In addition, the lecturer not only encouraged students to be active during speaking class, but also, she attempted to enhance students' creativity through certain topic like learning media exhibition. In managing the classroom, the new lecturer often implemented cooperative learning for several topics such as group discussion 
and learning media exhibition. In assessing students' speaking performance the new lecturer usually implemented oral test, and she also has her own scoring rubrics which consist of different criteria of each topic, for example pronunciation, content, and implementation of the strategy used for public speaking assessment.

Ultimately, the findings may also, to some extent, open to challenge and verification. It was suggested that the new lecturer should be able to implement more various ICT based learning. Also, they should also train the students to employ online and offline technology for education. In EFL contexts, it is an imperative factor which needs special attention and instruction (Richards \& Renandya, 2002, as cited in Gudu, 2015).

\section{REFERENCES}

Achmad, D. \& Yusuf, Y. Q. (2014).Observing Pair-Work Task in an English Speaking Class. International Journal of Instruction, 7(1): 151-164.

Beauchamp.C \& Thomas.L. (2011). New teachers' identity shifts at the boundary of teacher education and initial practice. International Journal of Educational Research50.p 6-13.

Bogdan, B. (1998). Qualitative Research for Education. USA: Allyn \& Bacon.

Costalesa.A. F, \&Martínezb. A. C. L. (2014). New approaches in English language teaching: teacher training in the framework of content and language integrated learning. Magister.26. $p$ 18-24.

Dashtestani, $R$. (2015). Towards integrating Computer-based Testing (CBT) into the EFL curriculum: Iranian EFL teachers' perspectives on challenges and obstacles. Asian EFL Journal. p, 134-163.

Gudu, B. O (2015). Teaching Speaking Skills in English Language using Classroom Activities in Secondary School Level in Eldoret Municipality, Kenya.

Krause, K.L \& Coates, H. (2008) Students' engagement in first-year university. Griffith Institute for Higher Education, Griffith University, Mount Gravatt, 4111, Queensland, Australia

Krashen.S. (2005). Is in-school free reading good for children? Why the national reading panel report is (still) wrong. The Phi Delta Kappan, 86(6). pp. 444-447

Levy. D. C. (1972). Creativity and the new teacher.National Art Education Association.(25)7. pp. 6-9. Retrieved from: http://www.jstor.org/stable/3191772

Maskat, N. (2010). New Teachers' Perception on the new academic staff pedagogical training module's learning logs - A report from a pilot study.Procedia Social and Behavioral Sciences.p, 376-382.doi:10.1016/j.sbspro.2010.10.051

Miller, J. (2003). Audible difference: ESL and social identity in schools. Clevedon: Multilingual matters.

Richards, J. C., \& Lockhart, C. (1996). Reflective teaching in second language classrooms. Cambridge: Cambridge University Press. 
Richard, J.C. (2013). Curriculum approaches in language teaching: Forward,central, and backward design. RELC Journal 2013.44(5). DOI:10.1177/0033688212473293. Retrieved from:http://rel.sagepub.com/content/44/1/5

Swaak. J, de Jongw. T \& Van Joolingenz W. R. (2004). The effects of discovery learning and expository instruction on the acquisition of definitional and intuitive knowledge. Journal of Computer Assisted Learning. 20. Pp225-234. Backwell Publishing Ltd.

Yunus, M. 2010. Improving Students' Speaking Skill through Guided Questions with Inside Outside Circle Technique at the First Grade of SMA Wahid Hasyim Malang Islamic University of Malang (UNISMA). Taken From http://repository.upi.edu/operator/upload/pro_2010_conaplin_muhammad yunus.pdf

Yunus, M. 2018. Teaching Critical Reading to Pre-Service Teachers Of English As A Foreign Language In Indonesia. Proceedings of International Seminar on English Language Teaching and Research (ELTAR) 2018 conducted by University of Islam Malang. Taken from http://eltar.inggrisppsunisma.ac.id/wpcontent/uploads/2018/04/62.-Muhammad-Yunus-582-592.pdf 